\title{
Seasonal Metabolic Acclimatization in Mountain Chickadees and Juniper Titmice
}

\author{
Sheldon J. Cooper \\ Department of Biology, Utah State University, Logan, Utah \\ 84322-5305
}

Accepted 4/18/02

\begin{abstract}
Mountain chickadees and juniper titmice from northern Utah were examined to determine metabolic and body-composition characteristics associated with seasonal acclimatization. These species use behavioral adaptations and nocturnal hypothermia, which reduce energetic costs. These adjustments could reduce the need for extensive metabolic adjustments typically found in small passerines that overwinter in cold regions. In addition, these species live at higher altitudes, which may also decrease metabolic acclimatization found in birds. Winter birds tolerated colder test temperatures than summer birds. This improved cold tolerance was associated with an increase in maximal thermogenic capacity or summit metabolism $\left(M_{\text {sum }}\right)$. Winter $M_{\text {sum }}$ exceeded summer $M_{\text {sum }}$ by $26.1 \%$ in chickadees and $16.2 \%$ in titmice. Basal metabolic rates (BMR) were also significantly higher in winter birds compared with summer birds. Pectoralis wet muscle mass increased $33.3 \%$ in chickadees and $24.1 \%$ in titmice in winter and paralleled the increased $M_{\text {sum }}$ and BMR. Dry mass of contour plumage increased in winter for both species and was associated with decreased thermal conductance in winter chickadees compared to summer chickadees. Chickadees and titmice show metabolic acclimatization similar to other temperate species.
\end{abstract}

\section{Introduction}

For small birds that overwinter in cold-temperate regions, the onset of winter creates energetically challenging conditions. These conditions include low air temperatures and decreased foraging time due to shorter days, which can be further restricted by snow or ice cover. Small birds meet this energetic

* Present address: Department of Biology and Microbiology, University of Wisconsin, Oshkosh, Wisconsin 54901-8640; e-mail: cooper@uwosh.edu.

Physiological and Biochemical Zoology 75(4):386-395. 2002. (C) 2002 by The University of Chicago. All rights reserved. 1522-2152/2002/7504-2005\$15.00 challenge primarily through metabolic adjustments (reviews: Dawson and Marsh 1989; Marsh and Dawson 1989a, 1989b; Dawson and O'Connor 1996). These metabolic adjustments generally include tolerance of colder temperatures in winteracclimatized birds relative to summer birds (Hart 1962; Barnett 1970; Pohl and West 1973), increased thermogenic endurance in winter birds (Dawson and Carey 1976; Dawson et al. 1983; Swanson 1990; O’Connor 1995), and increased summit metabolism $\left(M_{\text {sum }}\right)$ in winter birds (Hart 1962; Dawson and Smith 1986; Swanson 1990; Cooper and Swanson 1994; O'Connor 1995; Liknes and Swanson 1996).

The mountain chickadee (Poecile gambeli) and the juniper titmouse (Baeolophus griseus) are small, largely nonmigratory passerine birds that occupy regions of western North America. The mountain chickadee's distributional range extends to northern British Columbia $\left(60^{\circ} \mathrm{N}\right)$, whereas the juniper titmouse's range extends to portions of southern Oregon and Idaho (44 N; Godfrey 1986; Cicero 1996). In addition, mountain chickadees and juniper titmice live at relatively high altitudes ( 700-3,300 m; Bent 1946). Thus, both species inhabit regions that have severe winter climates. Seasonal acclimatization may be affected by high altitude. House finches from Colorado have a different pattern of seasonal acclimatization compared with Michigan house finches. Both Michigan and Colorado house finches have seasonal fattening, increased cold resistance, and increased catabolic capacity in winter. However, Colorado finches do not have seasonal changes in $M_{\text {sum }}$ as do Michigan finches (Dawson et al. 1983; O'Connor 1996). O'Connor (1996) states that these differences in seasonal acclimatization patterns may reflect either a direct or indirect response to the different altitudes of the study sites.

Mountain chickadees and juniper titmice have behavioral adaptations, including food caching and cavity roosting (Bent 1946), and use regulated bouts of nocturnal hypothermia (Cooper 1998), which reduce costs associated with temperate overwintering. For example, cavity roosting in mountain chickadees and juniper titmice can reduce nocturnal energy costs from $25 \%$ to $38 \%$ in winter (Cooper 1999). Because behavioral adaptations and nocturnal hypothermia reduce energetic costs, chickadees and titmice may not have as marked seasonal metabolic acclimatization compared to birds without these adaptations. However, black-capped chickadees from South Dakota show seasonal metabolic acclimatization similar to other temperate wintering passerines in addition to behavioral adaptations and nocturnal hypothermia (Cooper and Swanson 1994).

The aims of this study were to determine whether seasonal 
acclimatization in mountain chickadees and juniper titmice is similar to that in black-capped chickadees and other species that exhibit marked seasonal metabolic adjustments or whether behavioral adaptations and regulated hypothermia reduce seasonal metabolic adjustments in these birds. I also wanted to determine whether $M_{\text {sum }}$ changes seasonally in these highaltitude species. In addition, I wanted to determine whether changes in body composition are involved with seasonal metabolic acclimatization. Therefore, I studied seasonal variation in basal metabolic rate (BMR), cold tolerance, cold endurance, and maximal thermogenic capacity and body composition in mountain chickadees and juniper titmice from northern Utah.

\section{Material and Methods}

\section{Birds}

Mountain chickadees and juniper titmice were captured in summer and winter by mist net in 1994, 1995, and 1996. Mountain chickadees were captured in several locations within the Cache National Forest, Cache County, in northeastern Utah $\left(41^{\circ} 52^{\prime} \mathrm{N}, 111^{\circ} 30^{\prime} \mathrm{W}\right.$; altitude 1,800-2,300 m). Juniper titmice were captured near Rosette, Box Elder County, in northwestern Utah $\left(41^{\circ} 50^{\prime} \mathrm{N}, 113^{\circ} 25^{\prime} \mathrm{W}\right.$; altitude $\left.1,700-1,900 \mathrm{~m}\right)$. These study sites are characterized by cold winter climates (Fig. 1).

Body mass to the nearest $0.1 \mathrm{~g}$ was measured on capture with an Ohaus model CT-1200 portable electronic balance. Visible fat depots in abdominal and furcular regions were also scored on capture, using a scale of 0-5 (Helms and Drury 1960). Following capture, birds were transported to the laboratory, where they were housed individually in $0.3-\mathrm{m}^{3}$ cages in a $3-\mathrm{m}^{3}$ temperature-controlled environmental chamber. The chamber temperature and photoperiod followed a cycle that approximated the season and study site to which the bird had been accustomed. While caged, birds were provided water, grit, and food (Tenebrio larvae and wild bird seed) ad lib. All birds maintained mass while in captivity. Daytime metabolic tests were performed on birds after allowing the birds a minimum of 2 $\mathrm{h}$ of feeding. Chickadees tested from June 1 to August 21 and titmice tested from May 11 to August 14 were designated "summer birds.” Birds tested from November 25 to February 28 were designated "winter birds." For summer titmice, the $M_{\text {sum }}$ of birds tested in May $(n=5)$ was not significantly different from June to August $(t=0.64, P=0.53)$ and were therefore pooled with the June to August data.

\section{Body Composition}

Body composition was determined for a separate sample of wild birds captured before 0800 hours in summer and 0900 hours (MST) in winter. Birds were killed by cervical dislocation after body mass and fat scores were determined. Cervical dislocation was approved for use by the Utah State University Institutional Animal Care and Use Committee (protocol 602).

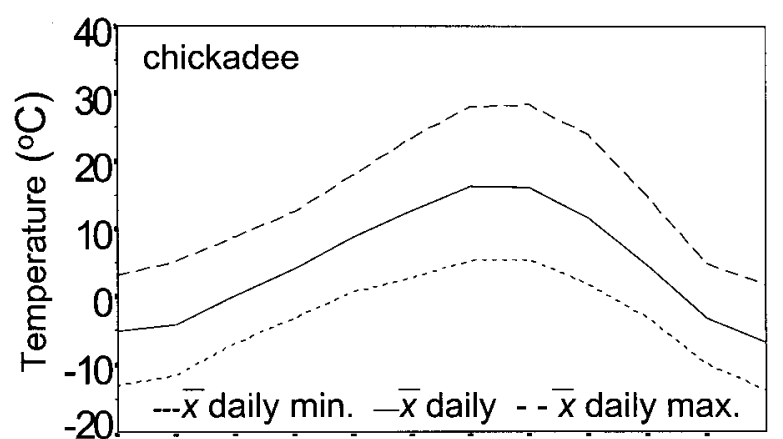

Jan Feb Mar Apr May Jun Jul Aug Sep Oct Nov Dec

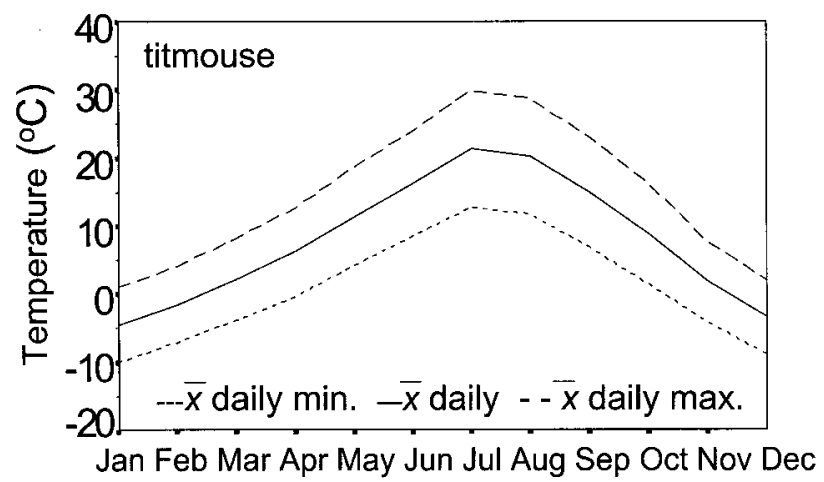

Figure 1. Annual temperature profiles for mountain chickadees and juniper titmice for study sites in northern Utah. Data are from the Utah Climate Center, Logan, 1989-1994.

The carcasses were then sealed in plastic bags, placed in an ice cooler in the field, and then stored in a freezer at $-20^{\circ} \mathrm{C}$ on return to the laboratory. Contour plumage mass was determined by plucking and drying contour feathers in an openended vial at $50^{\circ}-60^{\circ} \mathrm{C}$. The right pectoralis muscle was dissected out of each carcass, and wet mass was measured. Carcass (including right pectoralis muscle), remiges, and rectrices were minced and dried at $50^{\circ}-60^{\circ} \mathrm{C}$ to a constant mass. Neutral lipid was extracted from the dry carcass by Soxhlet extraction for 8 $h$ in petroleum ether (Dobush et al. 1985). Following the ether extraction, the lean carcass was air dried for $6 \mathrm{~h}$ and then oven dried at $50^{\circ}-60^{\circ} \mathrm{C}$ to constant mass. The difference between body mass at capture and dry mass equals the total body water. The difference between dry body mass and lean dry mass equals the extractable neutral lipid.

\section{Helox Cold Stress}

Cold-stress tests were conducted using a gas mixture of approximately $79 \%$ helium and $21 \%$ oxygen (helox). Helium is approximately four times more conductive than nitrogen. The high thermal conductivity of helox facilitates heat loss without impairing oxygen uptake and thereby allows maximal cold- 
induced thermogenesis or summit metabolism $\left(M_{\text {sum }}\right)$ at relatively moderate temperatures (Rosenmann and Morrison 1974). In addition, the effect of helox has been shown to be restricted to an increase in heat loss below the lower critical temperature in sugar gliders (Holloway and Geiser 2001). Coldstress tests were conducted by placing individual birds into a metabolic chamber constructed from a 3.8 -L paint can filled approximately one-third full with solid paraffin with the inner surface painted black to provide an emissivity near 1.0. The effective volume of the metabolic chamber was calculated according to Bartholomew et al. (1981) and was 2,660 mL in the absence of a bird. Helox was then passed through the chamber at metered rates, and oxygen consumption $\left(\dot{\mathrm{V}}_{\mathrm{O}_{2}}\right)$ was measured (see below). The metabolic chamber was placed inside an environmental chamber capable of regulating temperature $\pm 0.5^{\circ} \mathrm{C}$. Metabolic chamber temperature was monitored continuously throughout cold-stress tests with an Omega thermocouple thermometer (model Omni IIB, previously calibrated to a thermometer traceable to the U.S. Bureau of Standards) attached to a 30-gauge copper-constantan thermocouple inserted into the inlet port of the metabolic chamber approximately $5 \mathrm{~cm}$ above the bird's head. The metabolic chambers was periodically checked for leaks using a soap and water solution. No leaks were detected in the system.

Temperatures for cold stress were $6^{\circ}, 3^{\circ}$, and $0^{\circ} \mathrm{C}$ in summer and $0^{\circ},-3^{\circ},-6^{\circ},-9^{\circ}$, and $-12^{\circ} \mathrm{C}$ in winter. The lower temperatures at each season caused a majority of individuals to become hypothermic. Previous studies documenting $M_{\text {sum }}$ in passerines indicate that helox temperatures, resulting in hypothermia in a majority of individuals before $60 \mathrm{~min}$, elicit maximal thermogenesis and colder helox temperatures cause these birds to become rapidly hypothermic with depressed metabolic rates (Dawson and Smith 1986; Swanson 1990, 1993). Individual birds were exposed to a single temperature within the series for $65 \mathrm{~min}$ or until they became hypothermic (indicated by a steady decline in $\dot{\mathrm{V}}_{\mathrm{O}_{2}}$ over $3 \mathrm{~min}$ ). For titmice, four individuals were tested at a random second temperature within the series approximately $24 \mathrm{~h}$ after their first cold-stress test. This is because they became hypothermic at $-12^{\circ} \mathrm{C}$ within $15 \mathrm{~min}$, which gave no usable data. At the termination of each cold-stress test, birds were quickly removed from the chamber, and body temperature $\left(T_{\mathrm{b}}\left[ \pm 0.1^{\circ} \mathrm{C}\right]\right)$ was recorded within 30 $\mathrm{s}$ with a 30-gauge copper-constantan thermocouple attached to an Omega model HH25-TC thermometer (previously calibrated to a thermometer traceable to the U.S. Bureau of Standards). If it took longer than $30 \mathrm{~s}$ to record body temperature, the data were discarded since small birds can rewarm rapidly. The thermocouple was inserted into the cloaca to a depth where further insertion did not alter temperature reading (approximately 10-12 mm). Birds with a cloacal temperature less than $37^{\circ} \mathrm{C}$ were considered hypothermic.

\section{Summit Metabolic Rate}

Once a bird was in the chamber, I measured $\dot{\mathrm{V}}_{2}$ during helox cold stress using open-circuit respirometry. Dry, $\mathrm{CO}_{2}$-free helox from compressed gas cylinders was drawn through the metabolic chamber using a diaphragm pump. Outlet flow rates of 1,096-1,118 $\mathrm{mL} \min ^{-1}$ were maintained by a Matheson precision rotameter (model 604 ), calibrated with helox to $\pm 1 \%$ volumetrically (Brooks vol-u-meter, Brooks Instrument Division, Hatfield, Pa.), located downstream from the metabolic chamber. These flow rates yielded changes in oxygen content between influx and efflux gas of $0.3 \%-0.7 \%$ and maintained oxygen content of efflux gas above $20.2 \%$. In addition, these flow rates allowed the gas mixture within the metabolic chamber to reach $99 \%$ equilibrium in $\simeq 11 \mathrm{~min}$, as calculated using the equation of Lasiewski et al. (1966). Fractional concentration of oxygen in dry, $\mathrm{CO}_{2}$-free efflux gas was determined from a $100 \mathrm{~mL} \mathrm{~min}^{-1}$ subsample using an Ametek model S-3A oxygen analyzer (Pittsburgh). Measurements of dry, $\mathrm{CO}_{2}$-free efflux gas were recorded every $10 \mathrm{~s}$ on a computer using Datacan 5.0 data collection and analysis software (Sable Systems International, Henderson, Nev.). Oxygen consumption values were calculated according to the method of Bartholomew et al. (1981). I analyzed $M_{\text {sum }}$ data according to Dawson and Smith (1986) by averaging $\dot{\mathrm{Vo}}_{2}$ over consecutive 10-min intervals (1-10, 2-11, etc.). The highest 10 -min mean $\dot{\mathrm{V}}_{2}$ was considered $M_{\text {sum }}$ at the test temperature. The first $15 \mathrm{~min}$ of $\dot{\mathrm{V}}_{2}$ measurements were omitted from calculations in order for efflux oxygen concentration readings to stabilize. Tests were conducted on the day of capture or on the day after capture from 1100 to 1700 hours (MST).

\section{Basal Metabolic Rate Measurements}

Procedures used to measure BMR were similar to those for $M_{\text {sum }}$ except that air was used rather than helox. For BMR, chamber temperature ranged from $20^{\circ}$ to $30^{\circ} \mathrm{C}$, which is within the thermal neutral zone for both the mountain chickadee and juniper titmouse (Cooper 1998). BMR was measured from 2200 to 0300 hours in summer and from 2100 to 0400 hours (MST) in the winter. Birds were fasted for at least $4 \mathrm{~h}$ before testing to insure postabsorptive conditions. Dry, $\mathrm{CO}_{2}$-free air was drawn through the metabolic chamber at outlet flow rates of 442-450 $\mathrm{mL} / \mathrm{min}$. After a $1-\mathrm{h}$ equilibration period, metabolic rates were determined as the mean $\dot{\mathrm{V}}_{2}$ over a 60 -min period. Oxygen consumption was calculated as steady-state $\dot{\mathrm{V}}_{\mathrm{O}_{2}}$ using equation $4 a$ of Withers (1977). All values for $\dot{\mathrm{V}}_{2}$ were corrected for STP.

\section{Statistics}

All means are presented with their corresponding standard deviations. In order to determine $M_{\text {sum }}$, I compared $\dot{\mathrm{V}}_{2}$ of more 
than two groups using one-way ANOVA. Seasonal means of cold endurance, $M_{\text {sum }}$, and BMR were compared using twotailed Student's $t$-tests as variances and were not significantly different (F-tests for equality of variances). All data are presented on a whole-organism basis because this may be more instructive when doing seasonal comparisons (Dawson and Smith 1986; Swanson 1991a), and it avoids confounding effects of ratios (Packard and Boardman 1999). The effect of helox $T_{\mathrm{a}}$ on $T_{\mathrm{b}}$ was analyzed by least squares regression. Birds that became hypothermic in less than $25 \mathrm{~min}$ had substantially lower $M_{\text {sum }}$ than birds that remained normothermic for longer periods and were omitted from calculations of mean $M_{\text {sum }}$ (Koteja 1986). Statistical significance was accepted at $P<0.05$. All statistics were computed with SPSS 6.1 (SPSS, Chicago).

\section{Results}

\section{Body Mass and Condition}

Mean morning mass at capture for chickadees was significantly lower in winter than summer $(t=2.66, P<0.01)$. Mean morning mass at capture for titmice did not vary seasonally $(t=$ $0.38, P=0.71$; Table 1).

Visible fat depots in furcular and abdominal regions did not vary seasonally in titmice (furcular: $t=0.38, P=0.71$; abdominal: $t=-0.41, P=0.68)$. Winter chickadees had significantly higher furcular fat scores than in summer $(t=-2.41$, $P<0.05)$ but did not vary seasonally in abdominal fat scores $(t=-1.58, P=0.11)$. Fat content did not vary seasonally in chickadees $(t=0.08, P=0.94)$ or titmice $(t=0.25, P=$ 0.81; Table 1).

Contour plumage mass in winter was significantly higher in chickadees $(t=-6.65, P<0.001)$ and in titmice $(t=-4.06$, $P<0.001)$.

Winter contour plumage mass represents increases of $104 \%$ and $46 \%$ over summer contour plumage mass in chickadees and titmice, respectively (Table 1 ). Pectoralis mass was significantly higher in winter chickadees $(t=-2.60, P=0.02)$ and in winter titmice $(t=-2.75, P=0.25)$ compared to their summer counterparts (Table 1).

\section{Cold Tolerance and Body Temperature}

Both species were tolerant of colder helox temperatures in winter than in summer (Fig. 2). For example, greater than $50 \%$ of all summer chickadees and titmice became hypothermic from $0^{\circ}$ to $6^{\circ} \mathrm{C}$, while in winter it took temperatures from $-6^{\circ}$ to $-12^{\circ} \mathrm{C}$ to induce hypothermia in greater than $50 \%$ of all individuals tested. In winter, titmice were unable to tolerate helox cold stress at $-12^{\circ} \mathrm{C}(n=4)$ for more than $15 \mathrm{~min}$ and were omitted from $M_{\text {sum }}$ calculations. The average time it took for summer birds to become hypothermic in helox was $38.0 \mathrm{~min}$ for chickadees $(n=19)$ and $42.0 \mathrm{~min}$ for titmice $(n=13)$. In winter, the average time it took to become hypothermic in helox was $44.8 \mathrm{~min}$ for chickadees $(n=24)$ and $37.5 \mathrm{~min}$ for titmice $(n=13)$. For chickadees, the increased time to hypothermia in winter relative to summer was not significant $(t=-1.34$, $P=0.19$ ).

Mean $T_{\mathrm{b}}$ of normothermic birds after helox cold stress in summer birds was $37.7^{\circ} \pm 0.6^{\circ} \mathrm{C}(n=7)$ for chickadees and $38.3^{\circ} \pm 1.1^{\circ} \mathrm{C}(n=10)$ for titmice. For winter birds, mean $T_{\mathrm{b}}$ of normothermic birds after helox cold stress was $37.9^{\circ} \pm$ $1.1^{\circ} \mathrm{C}(n=3)$ for chickadees and $37.7^{\circ} \pm 0.5^{\circ} \mathrm{C}(n=3)$ for titmice. For birds remaining normothermic throughout helox cold-stress tests, $T_{\mathrm{b}}$ was independent of $T_{\mathrm{a}}$ in helox (summer: chickadees, $r^{2}=0.003, F=0.02, P=0.91$; titmice, $r^{2}=$ $0.25, F=2.60, P=0.15$; winter: chickadees, $r^{2}=0.21, F=$ $0.27, P=0.70$; titmice, $\left.r^{2}=0.43, F=0.75, P=0.55\right)$.

Cold tolerance may be influenced by seasonal variation in thermal conductance; therefore, thermal conductance was calculated for individual birds using the equation $C=$

Table 1: Seasonal values of morning body mass and composition for mountain chickadees and juniper titmice

\begin{tabular}{|c|c|c|c|c|}
\hline \multirow{3}{*}{$\frac{\text { Measurement }}{\text { Body mass (g) }}$} & \multicolumn{2}{|l|}{ Summer } & \multicolumn{2}{|l|}{ Winter } \\
\hline & Chickadees & Titmice & Chickadees & Titmice \\
\hline & $11.2 \pm .68(50)$ & $16.9 \pm .80(20)^{\mathrm{a}}$ & $10.8 \pm .77(46)^{\mathrm{b}}$ & $.97(13)^{\mathrm{a}}$ \\
\hline Fat content $(\mathrm{g})$ & $.36 \pm .09(8)$ & $.77 \pm .18(4)$ & $.36 \pm .13(7)$ & $.34(4)$ \\
\hline \multicolumn{5}{|l|}{ Visible fat: } \\
\hline Furcular & $.06 \pm .24(50)$ & $.19 \pm .54(16)$ & $.29 \pm .58(46)^{\mathrm{b}}$ & $.33(9)$ \\
\hline Abdominal & $.22 \pm .42(50)$ & $.06 \pm .25(16)$ & $.39 \pm .61(46)$ & $.33(9)$ \\
\hline Lean dry mass (g) & $2.84 \pm .23(8)$ & $4.88 \pm .39(4)$ & $2.79 \pm .37(7)$ & $4.41 \pm$ \\
\hline Body water (g) & $8.17 \pm .80(8)$ & $11.23 \pm .84(6)$ & $8.24 \pm .99(7)$ & $11.62 \pm 1.90$ \\
\hline Contour plumage mass (g) & $.28 \pm .08(7)$ & $.46 \pm .09(6)$ & $.57 \pm .09(7)^{\mathrm{b}}$ & $.67 \pm .05(4)^{\mathrm{b}}$ \\
\hline Pectoralis mass (g) & $.78 \pm .14(8)$ & $.80 \pm .13(6)$ & $1.04 \pm .24(7)^{\mathrm{b}}$ & $.15(4)^{\mathrm{b}}$ \\
\hline
\end{tabular}

Note. Sample size is given in parentheses. All data are reported as means $\pm \mathrm{SD}$.

${ }^{a}$ There were three additional titmice tested in both summer and winter for which morning body mass was not recorded.

${ }^{\mathrm{b}}$ Indicates significant difference in seasonal intraspecific comparisons $(P<0.05)$. 

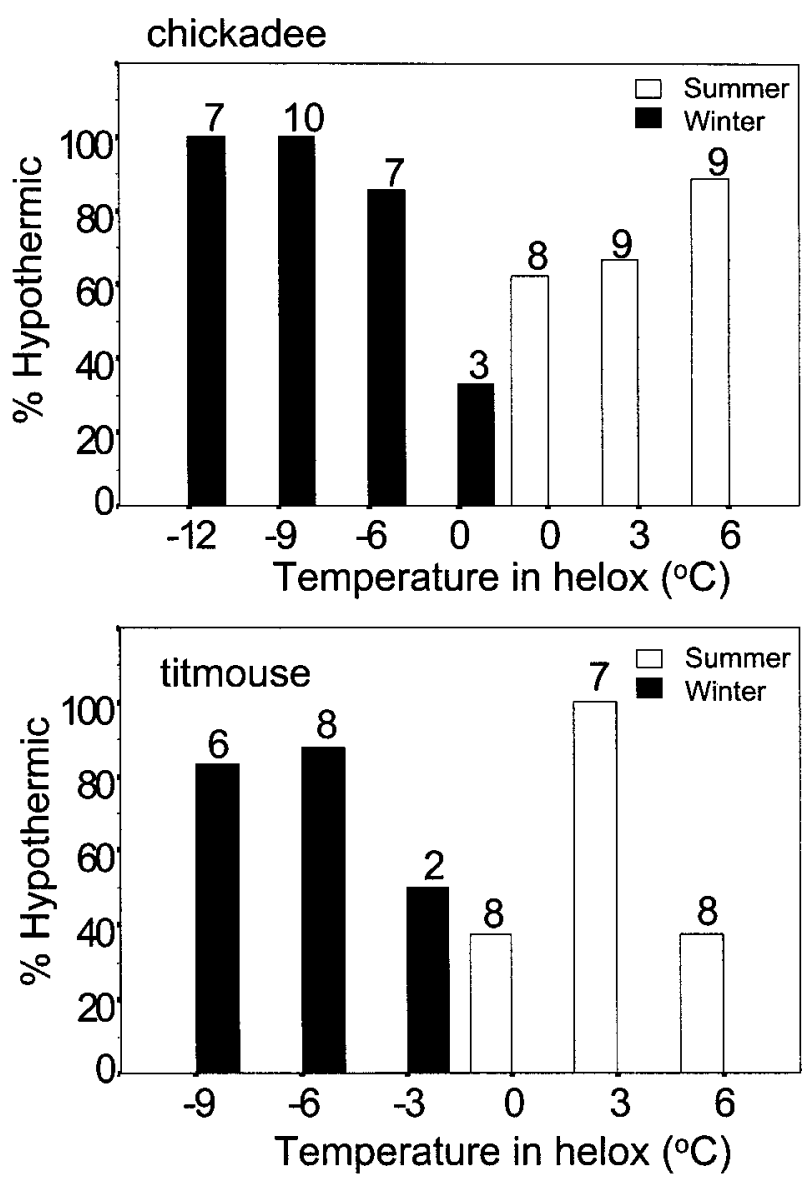

Figure 2. Cold tolerance for seasonally acclimatized mountain chickadees and juniper titmice over the 65 -min test period. Bars represent percentage of individuals that became hypothermic. Numbers above bars indicate sample size.

$M_{\text {sum }} /\left(T_{\mathrm{b}}-T_{\mathrm{a}}\right)$ (Scholander et al. 1950). Thermal conductance was calculated using the $M_{\text {sum }}$ and $T_{\mathrm{b}}$ for each individual measured at each test temperature. Thermal conductance for chickadees varied significantly between summer $\left(7.97 \pm 1.46 \mathrm{~mL} \mathrm{O}_{2}\right.$ $\left.\mathrm{h}^{-1}{ }^{\circ} \mathrm{C}^{-1}, n=25\right)$ and winter $\left(6.61 \pm 1.44 \mathrm{~mL} \mathrm{O}_{2} \mathrm{~h}^{-1}{ }^{\circ} \mathrm{C}^{-1}\right.$, $n=22, t=3.21, P<0.01)$. Conductance for titmice did not vary significantly between summer $\left(8.56 \pm 0.92 \mathrm{~mL} \mathrm{O} \mathrm{h}^{-1}\right.$ $\left.{ }^{\circ} \mathrm{C}^{-1}, n=22\right)$ and winter $\left(8.35 \pm 1.57 \mathrm{~mL} \mathrm{O}_{2} \mathrm{~h}^{-1}{ }^{\circ} \mathrm{C}^{-1}, n=\right.$ $15, t=0.53, P=0.60)$.

\section{Summit Metabolic Rate}

$M_{\text {sum }}$ varied seasonally in chickadees and titmice, with maximum values occurring in winter (Table 2). For chickadees, $M_{\text {sum }}$ did not vary with helox temperatures during summer, and $M_{\text {sum }}$ represents pooled values over the $0^{\circ}-6^{\circ} \mathrm{C}$ range tested $\left(F_{2,23}=0.09, P=0.92\right.$; Fig. 3$)$. For summer titmice, $M_{\text {sum }}$ did vary with helox temperatures $\left(F_{2,20}=6.15, P<0.01\right)$. Pairwise mean comparisons were made using Tukey's test, and birds at $0^{\circ} \mathrm{C}$ had significantly higher $M_{\text {sum }}$ than at $6^{\circ} \mathrm{C}$. However, birds at $0^{\circ} \mathrm{C}$ were not different from those at $3^{\circ} \mathrm{C}$, and birds at $3^{\circ} \mathrm{C}$ were not significantly different from those at $6^{\circ} \mathrm{C}$. Therefore, I pooled $M_{\text {sum }}$ over the helox temperature range for summer titmice (Fig. 3). In winter titmice, $\dot{\mathrm{V}}_{\mathrm{O}_{2}}$ did not vary with helox temperatures, and $M_{\text {sum }}$ represents pooled values over the $-3^{\circ}$ to $-9^{\circ} \mathrm{C}$ temperature range $\left(F_{2,13}=1.23, P=0.32\right)$. For winter chickadees, $\dot{\mathrm{V}}_{2}$ varied significantly with helox temperature $\left(F_{3,23}=5.32, P<0.01\right)$. Pairwise mean comparisons using Tukey's test showed that $\dot{\mathrm{V}}_{2}$ was significantly higher at $-9^{\circ} \mathrm{C}$ compared with other test temperatures, and this rate was used as the $M_{\text {sum }}$ (Fig. 3).

Winter chickadees had higher $M_{\text {sum }}(t=2.71, P=0.001)$ than summer chickadees. Winter titmice also had higher $M_{\text {sum }}$ relative to summer titmice ( $t=3.05, P=0.004$; Table 2 ).

\section{Basal Metabolic Rate}

Both species had significantly greater BMR in winter than in summer. BMR for winter chickadees $(n=17)$ was significantly higher relative to summer chickadees $(n=14, t=2.21, P=$ 0.035). The BMR $(t=3.89, P<0.001)$ for winter titmice $(n=12)$ was higher than for summer titmice $(n=16$; Table $2)$. Factorial increments in BMR were 1.17 in winter for chickadees and 1.22 for titmice. BMR exceeded allometrically predicted values (Aschoff and Pohl 1970) by 9.6\% for summer chickadees and $27.4 \%$ for winter chickadees. For summer titmice, BMR was $2.4 \%$ lower than allometric predictions and $12.8 \%$ lower than BMR in juniper titmice from southeastern Arizona (Weathers and Greene 1998). For winter titmice, BMR was $13.1 \%$ higher than allometrically predicted.

\section{Discussion}

\section{Body Mass and Composition}

Juniper titmice in this study did not show seasonal variation in morning body mass, visible fat, or fat content. The decreased morning body mass of winter-acclimatized mountain chickadees was probably due to increased length of overnight fasting compared to summer. Evening body masses for chickadees during BMR tests were equivalent in summer and winter chickadees (Table 2). Although visible fat in the furcular region was increased in winter compared with summer for chickadees, overall fat content did not vary seasonally. Increased body mass and fat stores are a common pattern of many cold-temperate wintering passerines, enabling these birds to meet thermoregulatory demands and buffer against temporary foraging restriction due to inclement weather (King 1972; Dawson and Marsh 1986; Waite 1992; O'Connor 1995). However, the body mass and fat scores of tree-foraging birds typically change little seasonally compared with ground-foraging birds. This is associated with more predictable food supplies in tree-foraging 
Table 2: Body mass and whole-organism metabolic rates for seasonally acclimatized mountain chickadees and juniper titmice from northern Utah

\begin{tabular}{lllllll}
\hline Species & Body Mass $(\mathrm{g})$ & BMR & Body Mass $(\mathrm{g})$ & $M_{\text {sum }}$ & $M_{\text {sum }} / \mathrm{BMR}$ \\
\hline Chickadee: & & & & & & \\
$\quad$ Summer & $11.1 \pm 1.1(14)$ & $.69 \pm .14$ & $11.4 \pm .9(26)$ & $4.26 \pm .77$ & 6.2 \\
$\quad$ Winter & $11.1 \pm 1.1(17)$ & $.81 \pm .17^{\mathrm{a}}$ & $11.0 \pm .9(10)$ & $5.37 \pm .77^{\mathrm{a}}$ & 6.6 \\
Titmouse: & & & & & & \\
$\quad$ Summer & $16.1 \pm .8(16)$ & $.81 \pm .09$ & $16.2 \pm 1.2(23)$ & $4.82 \pm .51$ & 6.0 \\
Winter & $17.2 \pm 1.1(12)^{\mathrm{a}}$ & $.99 \pm .16^{\mathrm{a}}$ & $17.0 \pm 1.1(16)^{\mathrm{a}}$ & $5.60 \pm 1.00^{\mathrm{a}}$ & 5.7 \\
\hline
\end{tabular}

Note. All data are reported as means \pm SD. Whole-organism metabolic rates are measured in milliliters $\mathrm{O}_{2}$ per minute. Body masses are means for the treatment group. Parenthetical values following body mass are sample sizes of the treatment groups.

${ }^{a}$ Indicates significant difference in seasonal intraspecific comparisons $(P<0.05)$.
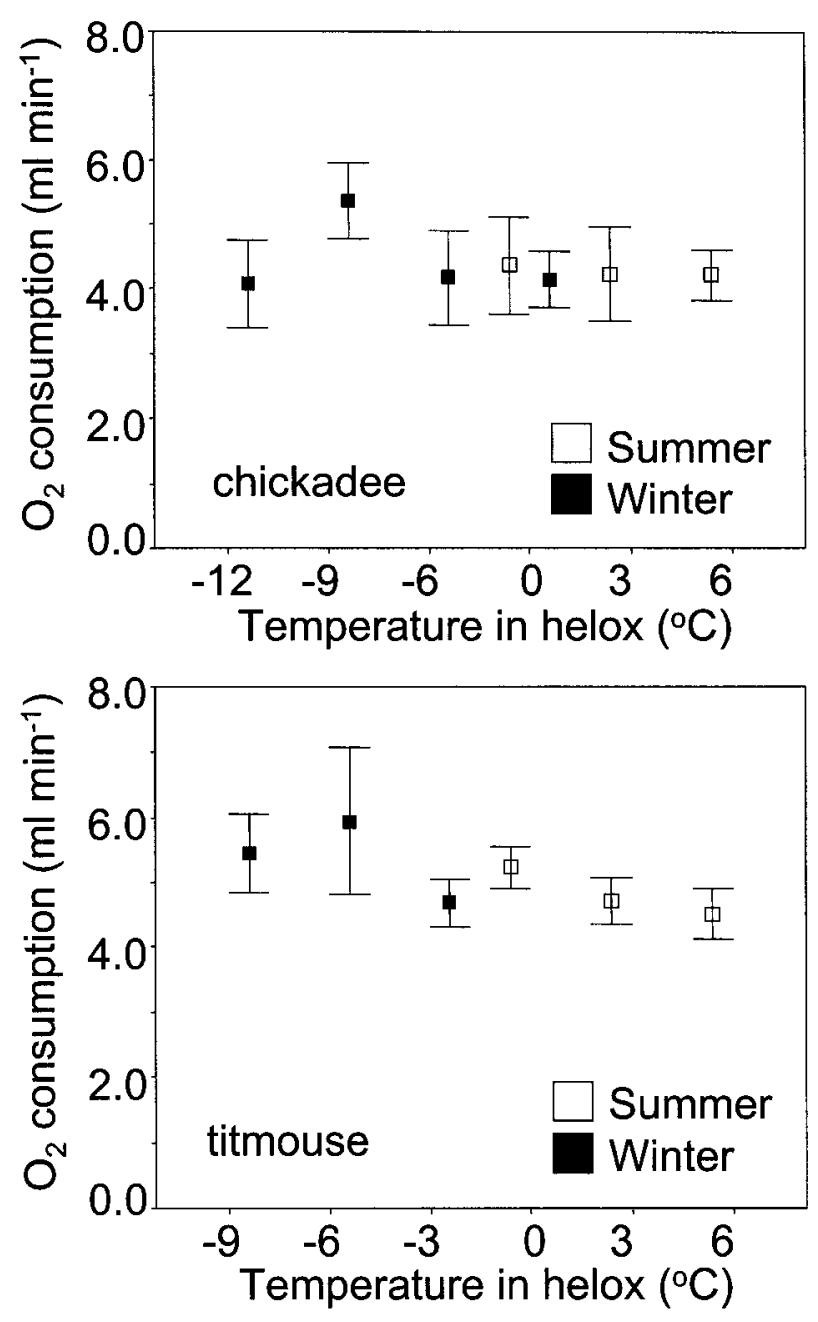

Figure 3. Whole-organism metabolism $\left(\mathrm{mL} \mathrm{O}_{2} \mathrm{~min}^{-1}\right)$ at various helox chamber temperatures for mountain chickadees (top) and juniper titmice (bottom). Means and 95\% confidence intervals are shown at each temperature. birds compared with ground-foraging birds (Rogers 1987; Rogers and Smith 1993). In addition, chickadees and titmice cache food in the fall for use in the winter (Bent 1946; Haftorn 1974). Therefore, minor seasonal changes in body mass in chickadees and titmice in this study agree with the findings of Rogers (1987).

Chaplin (1974) found winter increases in fat in black-capped chickadees from New York that were trapped in the afternoon. Consequently, seasonal variation in fat content in this study may have been underestimated. However, in several coldtemperate wintering passerines, significant winter increases in fat also occur in morning-captured birds (Dawson and Carey 1976; Swanson 1991a; Waite 1992; O’Connor 1995). This suggests that chickadees and titmice do not store fat in winter to the same degree as some other cold-temperate wintering passerines and that seasonal increases in fat stores are not a principal component of winter acclimatization in these birds.

\section{Cold Tolerance and Thermal Conductance}

Both species were tolerant of colder test temperatures in winter compared with summer. Thus, cold tolerance of both species appears to improve in winter (Fig. 2). Because test temperatures used in summer and winter were different from one another (except for chickadees at $0^{\circ} \mathrm{C}$ ), care should be used in these comparisons of cold tolerance. However, improved cold tolerance in winter-acclimatized birds is widespread in coldtemperate wintering species and is generally associated with increased thermogenic capacity (Marsh and Dawson 1986; Dawson and Marsh 1989; Swanson 1990; Cooper and Swanson 1994; O’Connor 1995; Liknes and Swanson 1996). Although cold exposure endurance did not increase significantly in these two species, increased cold tolerance is likely attributable to increased shivering endurance, which is closely linked to increased $M_{\text {sum }}$ (Marsh and Dawson 1989b; Bennett 1991; Swanson 2001). I estimated air temperature equivalents for helox test temperatures by inserting $M_{\text {sum }}$ into equations relating $\dot{\mathrm{VO}}_{2}$ to $T_{\mathrm{a}}$ below thermoneutrality (Cooper 1998) and solving 
Table 3: Enhancement of thermal conductance in helox compared to air for passerines

\begin{tabular}{lll}
\hline Species & $C_{\text {helox }} / C_{\text {air }}$ & Reference \\
\hline Common redpoll (Carduelis flammea) & 2.6 & Rosenmann and Morrison 1974 \\
American goldfinch (Carduelis tristis) & 2.7 & Dawson and Smith 1986 \\
House sparrow (Passer domesticus) & 1.72 & Koteja 1986 \\
Dark-eyed junco (Junco hyemalis) & 3.0 & Swanson 1990 \\
Black-capped chickadee (Poecile atricapillus) & 2.84 & Cooper and Swanson 1994 \\
Mountain chickadee (Poecile gambeli) & $2.50^{\mathrm{a}}$ & This study \\
Juniper titmouse (Baeolophus griseus) & $2.69^{\mathrm{a}}$ & This study \\
\hline
\end{tabular}

${ }^{\text {a }}$ Average of summer and winter $C_{\text {helox }} / C_{\text {air }}$ values.

for $T_{\mathrm{a}}$. Estimated air temperatures ranged from $-35.6^{\circ}$ to $-69.3^{\circ} \mathrm{C}$ for summer birds and from $-63.1^{\circ}$ to $-92.6^{\circ} \mathrm{C}$ for winter birds. This illustrates that both species are capable of tolerating acute cold exposure well below temperatures experienced under natural conditions.

In winter, thermal conductance in helox was $17 \%$ lower in chickadees than in summer. This indicates that winter chickadees are better insulated than their summer counterparts. Thermal conductance did not vary in titmice, indicating seasonally stable insulation. This suggests that chickadees have better insulation in winter, probably as a result of their increased contour plumage mass, but that increased contour plumage mass in titmice does not increase insulation. The increased contour plumage mass in titmice may provide better insulation in their natural environment, which includes forced convection due to wind. Thermal conductance in helox exceeded thermal conductance in air (Cooper 1998) in summer by 2.46 times in chickadees and by 2.90 times in titmice and in winter by 2.66 times in chickadees and by 2.47 times in titmice. These values are similar to factorial increments in minimal thermal conductance induced by helox cold stress in other temperate wintering passerines (Table 3 ). High factorial increments in minimal thermal conductance by helox cold stress indicate that heat loss in small birds is limited mainly by plumage insulation rather than body tissues such as subcutaneous fat (Dawson and Smith 1986). In addition, these values indicate that the importance of plumage insulation in chickadees and titmice is not markedly increased relative to other temperate wintering birds.

\section{Summit and Basal Metabolic Rates}

Both species had significantly elevated BMR and $M_{\text {sum }}$ in winter compared with summer. Increased BMR and $M_{\text {sum }}$ in winter for both chickadees and titmice demonstrate that metabolic adaptations are important components of winter acclimatization in these species. BMR varies seasonally in some passerines (Pohl and West 1973; Weathers and Caccamise 1978; Swanson 1991a; Cooper and Swanson 1994; Liknes and Swanson 1996) but not in others (Dawson and Carey 1976; Dawson et al. 1985; O'Connor 1995; Sharbaugh 2001).
In this study, pectoralis mass increased significantly in winter compared with summer for both chickadees and titmice. The $33.3 \%$ increase in pectoralis mass in chickadees parallels a $26.1 \%$ increase in $M_{\text {sum }}$ and a $17.4 \%$ increase in BMR in chickadees. The $24.1 \%$ increase in pectoralis mass parallels a $16.2 \%$ increase in $M_{\text {sum }}$ and a $22.2 \%$ increase in BMR in titmice. These data suggest that the winter increase in BMR for both species is at least partly due to the increased metabolic machinery of the pectoralis mass, which is needed for increased thermogenic capacity (Swanson 1991b). Pectoralis mass has also been found to be strongly correlated with BMR in house sparrows (Chappell et al. 1999). Similar increases in winter pectoralis muscle mass have been found in dark-eyed juncos (Swanson 1991b) and house finches (O'Connor 1995) and appear to be associated with increased $M_{\text {sum }}$ in these species. However, in house finches, BMR was seasonally stable in spite of increased pectoralis muscle mass in winter (O'Connor 1995). The possible adaptive significance and mechanistic basis of increased winter BMR in birds is not certain. Increased pectoralis mass in winter may be more important for elevation of $M_{\text {sum }}$ than BMR. If massspecific aerobic capacity remains seasonally static in chickadees and titmice, as reported for some other passerines (Marsh 1981; Yacoe and Dawson 1983), then any winter increase in pectoralis mass represents an increase in overall aerobic capacity. Even in birds that have a significantly higher mass-specific aerobic capacity in winter, the increase is generally low $(\sim 7 \%)$. Thus, an increase in pectoralis mass may provide the most significant increase in overall thermogenic capacity in winter birds.

Winter $M_{\text {sum }}$ on a whole-organism basis exceeds summer $M_{\text {sum }}$ by $26.1 \%$ in chickadees and by $16.2 \%$ in titmice. These values are within the range of winter increases in $M_{\text {sum }}$ in other passerines, which range from $0 \%$ to $52 \%$ greater than summer values (Marsh and Dawson 1989a; Liknes and Swanson 1996). The winter elevation of $M_{\text {sum }}$ for mountain chickadees is similar to the $36 \%$ increase in $M_{\text {sum }}$ recorded for winter black-capped chickadees (Cooper and Swanson 1994). $M_{\text {sum }}$ in summer was $5.0 \%$ lower for chickadees and $16.2 \%$ lower for titmice than allometrically predicted values. $M_{\text {sum }}$ in winter was $19.9 \%$ higher for chickadees and $6.7 \%$ lower for titmice than predicted using the allometric equation of Dutenhoffer and Swanson (1996), 
which was derived using $M_{\text {sum }}$ values for spring-, summer-, and winter-acclimatized passerines. These allometric comparisons of $M_{\text {sum }}$ demonstrate that winter chickadees are capable of markedly increased $M_{\text {sum }}$ compared with other passerines, but winter titmice are below predicted values from other temperate wintering passerines.

The increase in $M_{\text {sum }}$ in winter birds contrasts to data on house finches tested in Colorado at an elevation of 1,671 m. Colorado house finches have seasonally static $M_{\text {sum }}$. O'Connor (1996) states that the lack of seasonal variation in $M_{\text {sum }}$ in Colorado house finches may reflect direct physiological adjustments to altitude or indirect effects of high climatic variability associated with altitude. In either case, chickadees and titmice in this study that were captured and tested at high altitudes have seasonal variation in $M_{\text {sum }}$ that is similar to other species tested from lower altitudes.

Metabolic expansibilities $\left(M_{\text {sum }} / \mathrm{BMR}\right.$; Dawson and Carey 1976) for chickadees and titmice (Table 2) are similar to those recorded for black-capped chickadees in summer (6.7 times) and winter (7.9 times) and are among the highest recorded for birds, which range from 3.3 to 8.4 times (Marsh and Dawson 1986; Saarela et al. 1989; Lopez-Calleja and Bozinovic 1995; Dutenhoffer and Swanson 1996; Liknes and Swanson 1996).

These metabolic expansibilities demonstrate that mountain chickadees and juniper titmice are capable of elevating metabolism to a substantial degree to compensate for high rates of heat loss at cold winter temperatures. In addition, these metabolic expansibilities demonstrate that chickadees and titmice are able to elevate metabolism under cold stress in spite of behavioral adaptations such as food caching and using regulated nocturnal hypothermia (Bent 1946; Cooper 1998).

\section{Acknowledgments}

James Gessaman, Kim Sullivan, and two anonymous reviewers provided many useful suggestions on earlier drafts of this manuscript. James Gessaman provided lab space at Utah State University. Thanks to Keith Dixon for providing information on study sites and to Jaclyn Cooper, Dan Roberts, and Glenn Wilson for field assistance. This study was supported in part by a North American Bluebird Society student research grant, a Sigma Xi Grant-in-Aid of Research, and funding from the Ecology Center at Utah State University to James Gessaman. Birds were captured under federal (PRT-779300) and state (2COLL1401) scientific collecting permits.

\section{Literature Cited}

Aschoff J. and H. Pohl. 1970. Rhythmic variations in energy metabolism. Fed Proc 29:1541-1552.

Barnett L.B. 1970. Seasonal changes in temperature acclima- tization of the house sparrow, Passer domesticus. Comp Biochem Physiol 33:559-578.

Bartholomew G.A., D. Vleck, and C.M. Vleck. 1981. Instantaneous measurements of oxygen consumption during preflight warm-up and post-flight cooling in sphingid and saturniid moths. J Exp Biol 90:17-32.

Bennett A.F. 1991. The evolution of activity capacity. J Exp Biol 160:1-23.

Bent A.C. 1946. Life histories of North American jays, crows, and titmice. U.S. Natl. Mus. Bull. 191.

Chaplin S.B. 1974. Daily energetics of the black-capped chickadee, Parus atricapillus, in winter. J Comp Physiol 89: 321-330.

Chappell M.A., C. Bech, and W.A. Buttemer. 1999. The relationship of central and peripheral organ masses to aerobic performance variation in house sparrows. J Exp Biol 202: 2269-2279.

Cicero C. 1996. Sibling species of titmice in the Parus inornatus complex (Aves: Paridae). Univ Calif Publ Zool 128:1-217.

Cooper S.J. 1998. The Role of Cold Acclimatization on the Biogeography of the Mountain Chickadee (Parus gambeli) and the Juniper Titmouse (Parus ridgwayi). PhD diss. Utah State University, Logan.

- 1999. The thermal and energetic significance of cavity roosting in mountain chickadees and juniper titmice. Condor 101:863-866.

Cooper S.J. and D.L. Swanson. 1994. Seasonal acclimatization of thermoregulation in the black-capped chickadee. Condor 96:638-646.

Dawson W.R., W.A. Buttemer, and C. Carey. 1985. A reexamination of the metabolic response of house finches to temperature. Condor 87:424-427.

Dawson W.R. and C. Carey. 1976. Seasonal acclimatization to temperature in cardueline finches. I. Insulative and metabolic adjustments. J Comp Physiol 112:317-333.

Dawson W.R. and R.L. Marsh. 1986. Winter fattening in the American goldfinch and the possible role of temperature in its regulation. Physiol Zool 59:353-369.

. 1989. Seasonal acclimatization to cold and season in birds. Pp. 83-94 in C. Bech and R.E. Reinertsen, eds. Physiology of Cold Adaptation in Birds. Plenum, New York.

Dawson W.R., R.L. Marsh, W.A. Buttemer, and C. Carey. 1983. Seasonal and geographic variation of cold resistance in house finches (Carpodacus mexicanus). Physiol Zool 56:353-369.

Dawson W.R. and T.P. O'Connor. 1996. Energetic features of avian thermoregulatory responses. Pp. 85-124 in C. Carey, ed. Avian Energetics and Nutritional Ecology. Chapman \& Hall, New York.

Dawson W.R. and B.K. Smith. 1986. Metabolic acclimatization in the American goldfinch (Carduelis tristis). Pp. 427-434 in H.C. Heller, X.J. Musacchia, and L.C.H. Wang, eds. Living in the Cold: Physiological and Biochemical Adaptations. Elsevier, New York. 
Dobush G.R., C.D. Ankney, and D.G. Krementz. 1985. The effect of apparatus, extraction time, and solvent type on lipid extractions of snow geese. Can J Zool 63:1917-1920.

Dutenhoffer M. and D.L. Swanson. 1996. Relationship of basal to summit metabolic rate in passerine birds and the aerobic capacity model for the evolution of endothermy. Physiol Zool 69:1232-1254.

Godfrey W.E. 1986. The Birds of Canada. National Museums of Canada, Ottawa.

Haftorn S. 1974. Storage of surplus food by the boreal chickadee Parus hudsonicus in Alaska, with some records on the mountain chickadee Parus gambeli in Colorado. Ornis Scand 5: 145-161.

Hart J.S. 1962. Seasonal acclimatization in four species of small wild birds. Physiol Zool 35:224-236.

Helms C.W. and W.H. Drury, Jr. 1960. Winter and migratory weight and fat field studies on some North American buntings. Bird-Banding 31:1-40.

Holloway J.C. and F. Geiser. 2001. Effects of helium/oxygen and temperature on aerobic metabolism in the marsupial sugar glider, Petaurus breviceps. Physiol Biochem Zool 74: 219-225.

King J.R. 1972. Adaptive periodic fat storage by birds. Pp. 200-217 in Proceedings of the 15th Ornithological Congress. Leiden, The Netherlands.

Koteja P. 1986. Maximum cold-induced oxygen consumption in the house sparrow Passer domesticus L. Physiol Zool 59: 43-48.

Lasiewski R.C., A.L. Acosta, and M.H. Bernstein. 1966. Evaporative water loss in birds. I. Characteristics of the open flow method of determination, and their relation to estimates of thermoregulatory ability. Comp Biochem Physiol 19: 445-457.

Liknes E.T. and D.L. Swanson. 1996. Seasonal variation in cold tolerance, basal metabolic rate, and maximal capacity for thermogenesis in white-breasted nuthatches Sitta carolinensis and downy woodpeckers Picoides pubescens, two unrelated arboreal temperate residents. J Avian Biol 27: 279-288.

Lopez-Calleja M.V. and F. Bozinovic. 1995. Maximum metabolic rate, thermal insulation and aerobic scope in a smallsized Chilean hummingbird (Sephanoides sephanoides). Auk 112:1034-1036.

Marsh R.L. 1981. Catabolic enzyme activities in relation to premigratory fattening and muscle hypertrophy in the gray catbird (Dumetella carolinensis). J Comp Physiol B 141: 417-423.

Marsh R.L. and W.R. Dawson. 1986. Role of metabolic adjustments in avian survival of cold winters. Proc Int Ornithol Congr 29:2690-2701.

—. 1989a. Avian adjustments to cold. Pp. 205-253 in L.C.H. Wang, ed. Advances in Comparative and Environmental Physiology. Springer, Berlin. 1989b. Energy substrates and metabolic acclimatization in small birds. Pp. 105-114 in C. Bech and R.E. Reinertsen, eds. Physiology of Cold Adaptation in Birds. Plenum, New York.

O'Connor T.P. 1995. Metabolic characteristics and body composition in house finches: effects of seasonal acclimatization. J Comp Physiol B 165:298-305.

- 1996. Geographic variation in metabolic seasonal acclimatization in house finches. Condor 98:371-381.

Packard G.C. and T.J. Boardman. 1999. The use of percentages and size-specific indices to normalize physiological data for variation in body size: wasted time, wasted effort? Comp Biochem Physiol 122A:37-44.

Pohl H. and G.C. West. 1973. Daily and seasonal variation in metabolic response to cold and forced exercise in the common redpoll. Comp Biochem Physiol 45A:851-867.

Rogers C.M. 1987. Predation risk and fasting capacity: do wintering birds maintain optimal body mass? Ecology 68: 1051-1061.

Rogers C.M. and J.N.M. Smith. 1993. Life-history theory in the nonbreeding period: trade-offs in avian fat reserves. Ecology 74:419-426.

Rosenmann M. and P. Morrison. 1974. Maximum oxygen consumption and heat loss facilitation in small homeotherms by $\mathrm{HeO}_{2}$. Am J Physiol 226:490-495.

Saarela S., B. Klapper, and G. Heldmaier. 1989. Thermogenic capacity of greenfinches and siskins in winter and summer. Pp. 115-122 in C. Bech and R.E. Reinertsen, eds. Physiology of Cold Adaptation in Birds. Plenum, New York.

Scholander P.R., R. Hock, V. Walters, F. Johnson, and L. Irving. 1950. Heat regulation in some arctic and tropical mammals and birds. Biol Bull 99:237-258.

Sharbaugh S.M. 2001. Seasonal acclimatization to extreme climatic conditions by black-capped chickadees (Poecile atricapilla) in interior Alaska $\left(64^{\circ} \mathrm{N}\right)$. Physiol Biochem Zool 74: 568-575.

Swanson D.L. 1990. Seasonal variation in cold hardiness and peak rates of cold-induced thermogenesis in the dark-eyed junco (Junco hyemalis). Auk 107:561-566.

- 1991a. Seasonal adjustments in metabolism and insulation in the dark-eyed junco. Condor 93:538-545.

- $1991 b$. Substrate metabolism under cold stress in seasonally acclimatized dark-eyed juncos. Physiol Zool 64: 1578-1592.

- 1993. Cold tolerance and thermogenic capacity in dark-eyed juncos in winter: geographic variation and comparison with American tree sparrows. J Therm Biol 18: 275-281.

- 2001. Are summit metabolism and thermogenic endurance correlated in winter-acclimatized passerine birds? J Comp Physiol B 171:475-481.

Waite T.A. 1992. Winter fattening in gray jays: seasonal, diurnal, and climatic correlates. Ornis Scand 23:499-503. 
Weathers W.W. and D.F. Caccamise. 1978. Seasonal acclimatization to temperature in monk parakeets. Oecologia 35: 173-183.

Weathers W.W. and E. Greene. 1998. Thermoregulatory responses of bridled and juniper titmice to high temperature. Condor 100:365-372.
Withers P.C. 1977. Measurement of $\dot{\mathrm{V}}_{2}, \dot{\mathrm{V}}_{\mathrm{CO}_{2}}$, and evaporative water loss with a flow-through mask. J Appl Physiol 42: 120-123.

Yacoe M.E. and W.R. Dawson. 1983. Seasonal acclimatization in the American goldfinch: the role of the pectoralis muscle. Am J Physiol 245:R265-R271. 
Copyright $\odot 2002$ EBSCO Publishing 